\title{
EWOLUCJA POLITYKI BEZPIECZEŃSTWA JAPONII PO ZIMNEJ WOJNIE. OD „PAŃSTWA MORATORIUM” DO STRATEGICZNEJ „NORMALNOŚCI”
}

Polityka bezpieczeństwa Cesarstwa Japonii w okresie po II wojnie światowej jest nieprzerwanie obiektem żywego zainteresowania, zarówno praktyków, jak i badaczy stosunków międzynarodowych. Wynika to z dwóch zasadniczych przesłanek. Pierwszą stanowi tradycyjnie istotna pozycja tego państwa w międzynarodowym układzie sił regionu Azji (którego znaczenie dla ładu globalnego stale rośnie). Już w czasach Pax Sinica (umowne w przedziale 221 r. p.n.e.-1842 r. n.e.), Japonia zachowywała względną niezależność, a nawet okresowo przejawiała aspiracje mocarstwowe ${ }^{1}$. W połowie XIX w., pod wpływem kontaktu z ekspansją mocarstw europejskich i Stanów Zjednoczonych, Cesarstwo podjęło ambitny program transformacji politycznej, społecznej i gospodarczej, dzięki któremu, stało się pierwszym azjatyckim państwem uprzemysłowionym oraz mocarstwem o statusie porównywalnym z potęgami kolonialnymi. Pod koniec XIX w. Japonia rozpoczęła agresywną politykę ekspansji kolonialnej, której kulminacją stała się próba całkowitego zdominowania regionu, w ramach tzw. Strefy Wspólnego Dobrobytu Wielkiej Azji Wschodniej, w okresie II wojny światowej. Bezpośrednio po zakończeniu wojny wydawało się, iż pokonane i okupowane Cesarstwo trwale utraci pozycję istotnego aktora regionalnych stosunków bezpieczeństwa. Stosunkowo szybko jednak, nowy regionalny hegemon, w postaci USA, docenił strategiczne znaczenie pokonanego przeciwnika w kształtującym się systemie zimnowojennym.

Położenie geopolityczne Japonii determinuje jej kluczową rolę w regionalnym systemie interakcji strategicznych. Archipelag Wysp Japońskich, stanowi północny kraniec łańcucha wysp oddzielających basen Zachodniego Pacyfiku od wybrzeży kontynentu azjatyckiego. W wymiarze militarnym umożliwia to nie tylko sprawowanie kontroli nad szlakami żeglugowymi, ale również projekcję siły na kontynent (naturalnie również blokowanie projekcji siły na zewnątrz przez potęgi kontynentalne) ${ }^{2}$. Zatem strategiczne położenie oraz wysoko rozwinięta gospodarka przemysłowa zadecydowały o szczególnej wartości Japonii w zimnowojennej rozgrywce o strefy wpływów. W związku z tym priorytety okupanta uległy zmianie i w konsekwencji Cesarstwo stało się kluczowym

1 Pod koniec XVI wieku japoński wódz Hideyoshi podjął nieudaną próbę podboju Korei i Chin. Patrz: Y. Deng, China's Struggle for Status The Realignment of International Relations, Cambridge 2008, s. 40.

2 J. R. Holmes, Japanese Maritime Thought: If Not Mahan, Who?, w: Asia Looks Seaward Power and Maritime Strategy, eds. T. Yoshihara, J. R. Holmes, Westport 2008, s. 147-148. 
elementem amerykańskiego systemu sojuszy, zapewniającego powstrzymywanie komunizmu w Azji. W tamtym okresie wykształcił się kolejny czynnik wyróżniający Japonię jako przedmiot badań. W wyniku przemyślanej polityki rozwojowej, państwo to szybko stało się jedną z wiodących potęg gospodarczych świata, jednak nie towarzyszył temu oczekiwany wzrost potęgi militarnej i znaczenia politycznego. U zarania zimnej wojny japońscy przywódcy przyjęli oryginalną strategię polityki zagranicznej i bezpieczeństwa, opartą na wyrzeczeniu się instrumentów siłowych i ograniczeniu potencjału obronnego do niezbędnego minimum. Ograniczenia prawne, przyjęcie koncepcji wszechstronnego bezpieczeństwa oraz silne nastroje pacyfistyczne i antymilitarystyczne społeczeństwa doprowadziły do przyjęcia przez Cesarstwo międzynarodowej postawy ,pacyfistycznego państwa handlowego”. Taka polityka mocno kontrastowała z poczynaniami innych znaczących aktorów ówczesnego ładu międzynarodowego. Była również trudna do wythumaczenia z punktu widzenia tradycyjnej perspektywy wyjaśniania stosunków międzynarodowych (opartej na realizmie politycznym), w myśl której wzrost potencjału gospodarczego państwa powinien prowadzić do mocarstwowych aspiracji i wzmożonych zbrojeń. Strategia ta przyniosła jednak niespodziewany sukces, co doprowadziło niektórych obserwatorów do konkluzji, iż Japończycy znaleźli nową formułę polityki zagranicznej państwa, lepiej dostosowaną do szybko globalizującego się świata ${ }^{3}$.

Niezwykle intrygującym pozostaje fakt, iż zasadnicza transformacja ładu międzynarodowego (tak w wymiarze globalnym, jak i regionalnym), którą przyniósł koniec zimnej wojny, zapoczątkowała proces ewolucji japońskiej polityki bezpieczeństwa w przeciwnym od dotychczasowego kierunku. Bardziej niepewne środowisko bezpieczeństwa, uwarunkowania sojuszu z USA, oraz istotne zmiany w systemie politycznym państwa doprowadziły do stopniowego odejścia od formuły drastycznie ograniczonego potencjału obronnego na rzecz rozbudowy sił zbrojnych i wypełniania przez nie coraz szerszego wachlarza misji. Odpowiedź na pytanie o treść i zakres tych zmian, ich przyczyny oraz konsekwencje ma istotne znaczenie dla analizy obecnego i przyszłego kształtu środowiska bezpieczeństwa międzynarodowego w Azji.

\section{POLITYKA BEZPIECZEŃSTWA JAPONII W OKRESIE ZIMNEJ WOJNY - PAŃSTWO MORATORIUM}

Bezpośrednio po zakończeniu II wojny światowej japońscy przywódcy stanęli przed koniecznością wypracowania nowej formuły określającej miejsce ich państwa w systemie międzynarodowym. Musieli tego dokonać w warunkach ruiny gospodarczej, kompletnej kompromitacji przedwojennego systemu politycznego oraz obcej okupacji. Do czasu podpisania traktatu pokojowego i przywrócenia suwerenności najważniejsze decyzje podejmowały władze amerykańskie. Jednak zasadnicze założenia japońskiej polityki zagranicznej i bezpieczeństwa zostały wypracowane przez rodzimych przywódców. W praktyce oznaczało to wąską elitę biurokratów, która odgrywała s. 3-6.

${ }^{3}$ K. B. Pyle, Japan Rising The Resurgence of Japanese Power and Purpose, Nowy Jork 2007, 
kluczową rolę w japońskim systemie politycznym od czasów Mieji, i z której pomocy przy administrowaniu państwem korzystały władze okupacyjne.

Decydenci musieli jednak uwzględniać silny wpływ przeciwstawnych tendencji i nacisków. Z jednej strony nowy system polityczny, narzucony przez okupanta, wprowadzał realnie rządy parlamentarne, co w połączeniu z rosnącą świadomością (i aktywnością) obywatelską społeczeństwa nie pozwalało rządzącym na ignorowanie nastrojów opinii publicznej. W sposób zrozumiały (biorąc pod uwagę rozmiar cierpień i zniszczeń, które przyniosła wojna) społeczeństwo wykazywało silne nastroje pacyfistyczne $i$ antymilitarystyczne. Ich politycznymi wyrazicielami były partie socjalistyczna i komunistyczna, które bezpośrednio po wojnie cieszyły się szerokim poparciem społecznym. Kluczowym elementem ich programu był postulat całkowitego rozbrojenia i ścisłej neutralności w rodzącej się rywalizacji bloków polityczno-wojskowych. Jednocześnie USA były gotowe objąć Japonię sojuszniczymi gwarancjami bezpieczeństwa, jednak oczekiwały, iż Cesarstwo podejmie część obowiązków (i kosztów) związanych z realizacją strategii powstrzymywania komunizmu w Azji. Stosunkowo szybko Amerykanie stworzyli ambitne plany remilitaryzacji Japonii i włączenia jej w regionalny system sojuszy wojskowych. Równocześnie, w samej Japonii wpływowa grupa polityków konserwatywnych (za jej czołowych przedstawicieli można uznać Ichiro Hatoyamę oraz Nobusuke Kishiego) głosiła program powrotu do mocarstwowej pozycji poprzez odbudowę sił zbrojnych i prowadzenie niezależnej polityki zagranicznej.

Największe wpływy uzyskała jednak ostatecznie grupa umiarkowanych konserwatystów z premierem Shigeru Yoshidą na czele ${ }^{4}$. To właśnie oni sformułowali strategię, która określiła międzynarodową pozycję Japonii na kolejne 40 lat. Warto zaznaczyć, iż kierowali się oni nadzwyczaj trwałymi zasadami japońskiej kultury strategicznej, które ukształtowały się jeszcze w okresie feudalnym i pozostają żywe w polityce Cesarstwa praktycznie do czasów współczesnych. Amerykański badacz Kenneth B. Pyle w swej dogłębnej analizie japońskiej polityki zagranicznej, wskazał na sześć zasadniczych wzorów postępowania właściwych japońskiej polityce zagranicznej ${ }^{5}$. Dla zrozumienia nowej powojennej strategii szczególne znaczenie mają trzy z nich: ranga i honor, autonomia i hegemonia regionalna oraz adaptacja i przystosowanie.

Stronnicy Yoshidy nie zamierzali wyrzekać się aspiracji do odgrywania przez Japonię roli mocarstwa regionalnego i liczącej się potęgi światowej. Innowacyjny miał być natomiast sposób osiagnięcia tego celu. Od czasów rewolucji Meiji do ostatecznej klęski w II wojnie światowej Japończycy próbowali narzucić Azji swą dominację przy pomocy siły militarnej. Taka strategia zakończyła się kompletną klęską. U jej podstaw leżała słabość gospodarczych podstaw japońskiej potęgi, szczególnie widoczna w konfrontacji ze Stanami Zjednoczonymi. W nowych, powojennych uwarunkowaniach było jasne, iż punktem wyjścia dla powrotu do mocarstwowości musi być odbudowa gospodarcza. W tej sytuacji za celowe uznano wprowadzenie nowej hierarchii priorytetów. Na jej szczycie miał się znaleźć rozwój gospodarczy, a na samym końcu kwestie militarne. Owocem nowego podejścia była tzw. doktryna Yoshidy, którą można

${ }_{5}^{4}$ Szerzej: K. B. Pyle, op. cit., s. 225-233.

5 Ibidem, s. 33-65. 
sprowadzić do trzech zasadniczych założeń $\left.{ }^{6}: 1\right)$ odbudowa gospodarcza musi być najważniejszym priorytetem narodowym; dla jego osiagnięcia niezbędna jest współpraca polityczno-gospodarcza z USA; 2) Japonia powinna ograniczyć zbrojenia do minimalnego poziomu niezbędnego do samoobrony i jednocześnie unikać zaangażowania w międzynarodowe stosunki polityczno-strategiczne; celem takiej postawy jest skupienie sił i środków na promowaniu rozwoju gospodarczego oraz uniknięcie nadmiernych kontrowersji w polityce wewnętrznej; 3) dla zapewnienia sobie długotrwałego bezpieczeństwa Japonia zezwoli na założenie na swym terytorium amerykańskich baz wojskowych.

Założenia, które legły u podstaw tej doktryny znalazły ostateczne potwierdzenie w koncepcji ,wszechstronnego bezpieczeństwa”, która została sformułowana w raporcie nieformalnej grupy studyjnej powołanej przez premiera Masayoshi Ōhirę (wydanym w $1980 \mathrm{r}$. $)^{7}$. Zgodnie $\mathrm{z}$ tą formułą bezpieczeństwo państwa we współczesnym świecie należy rozpatrywać na kilku płaszczyznach. Siła militarna, choć niezbędna dla zapewnienia bezpieczeństwa narodowego, jest mało użyteczna dla osiagania celów w polityce międzynarodowej i jej rola zasadniczo ogranicza się do samoobrony przed agresją. Na pierwszy plan wysunięto kwestie bezpieczeństwa ekonomicznego. Za najważniejsze instrumenty oddziaływania na środowisko międzynarodowe uznano relacje handlowe i pomoc rozwojowa. Koncepcja wszechstronnego bezpieczeństwa była faktycznie sformalizowaniem dotychczasowej praktyki polityki japońskiej i stanowi podstawę myślenia o bezpieczeństwie narodowym Cesarstwa praktycznie do dziś. Warto jednak pamiętać, iż była swoistym prekursorem nowego myślenia o kwestiach bezpieczeństwa, które rozpowszechniło się w doktrynach innych państw (oraz dyscyplinie studiów strategicznych) dopiero po zakończeniu zimnej wojny.

Jako podsumowanie rozważań nad intelektualnymi podstawami japońskiej polityki bezpieczeństwa w okresie zimnej wojny warto przybliżyć myśl Yonosuke Nagai wyrażoną w koncepcji „świata moratorium” oraz Japonii jako „państwa moratorium”. Zakładał on, iż system międzynarodowy znajduje się w fazie przejścia od tradycyjnego modelu westfalskiego (w którym najważniejszym wyznacznikiem pozycji państwa była siła militarna) do kantowskiego pokojowego porządku świata, w którym gwarantem bezpieczeństwa państw będą kolektywne porozumienia międzynarodowe. Fazę przejścia charakteryzuje według niego nuklearny pat między supermocarstwami, który wymusza swoiste moratorium na użycie siły zbrojnej w systemie międzynarodowym. Tym samym obok międzynarodowej hierarchii państw opartej na kryterium siły militarnej, pojawia się alternatywna stratyfikacja oparta na innych kryteriach, przede wszystkim ekonomicznych. Tym samym najlepszą strategią dla Japonii jest odrzucenie założenia o konieczności posiadania potencjału militarnego odpowiadającego wypracowanej kondycji gospodarczej. Zamiast tego postuluje przyjęcie postawy „państwa

6 Ibidem, s. 242.

7 G. D. Hook, J. Gilson, Ch. W. Hughes, H. Dobson, Japan's International Relations Politics, economics and security second edition, London 2005, s. 155 oraz E. Heginbotham, R. J. Samuels, Japan, w: Strategic Asia 2002-03: Asian Aftershocks, eds. R. J. Ellings, A. L. Friedberg, M. Wills, Seattle 2002, s. 98-99.

${ }^{8}$ K. B. Pyle, op. cit., s. 261-262. 
moratorium", koncentrującego się na rozwoju potencjału gospodarczego, którego podstawą są nowoczesne technologie.

Źródłem istotnych ograniczeń dla swobody kształtowania polityki bezpieczeństwa przez rządzących były również cechy systemu politycznego. Przejawiało się to zarówno na poziomie kultury politycznej, jak i samej struktury systemu partyjnego oraz procesu decyzyjnego w ramach władzy wykonawczej. Pod wpływem doświadczeń wojennych w społeczeństwie japońskim rozpowszechniły się postawy pacyfistyczne i antymilitarystyczne, które z czasem znalazły się wśród najważniejszych norm i wartości tworzących kulturę polityczną Cesarstwa. Głoszące program neutralności partie lewicowe mogły liczyć na poparcie wpływowych środowisk opiniotwórczych oraz zdolność do mobilizacji szerszej opinii publicznej w sprzeciwie wobec nazbyt ambitnych (w ich przekonaniu) inicjatyw rządu w sferze bezpieczeństwa narodowego. Doskonalą ilustracją tego stanu rzeczy były masowe protesty zorganizowane w 1960 r. przez przeciwników nowego traktatu sojuszniczego z USA. Odbyły się wówczas największe masowe demonstracje w powojennej historii Japonii i chociaż opozycji nie udało się zablokować ratyfikacji traktatu, to jednak kryzys polityczny wymusił rezygnację rewizjonistycznego premiera Nobusuke Kishiego. Od tamtej pory dla elit rządzących stało się jasne, iż prowadzenie polityki bezpieczeństwa wbrew opinii publicznej jest w nowych uwarunkowaniach ustrojowych praktycznie niemożliwe.

Warto jednak zaznaczyć, iż postawa społeczeństwa nie zawsze była tak nieprzejednana jak w czasie kryzysu 1960 r. Jak zauważył badacz tego zagadnienia Yasuhiro Izumikawa, postawy antymilitarystyczne w społeczeństwie japońskim były pochodną trzech czynników: pacyfizmu, antytradycjonalizmu oraz obaw przed uwikłaniem w konflikty prowadzone przez amerykańskiego sojusznika ${ }^{9}$. W swoim studium przedstawia on przekonujące argumenty na rzecz tezy, iż idee pacyfistyczne były tylko jednym z motywów warunkujących nastroje antymilitarystyczne i to niekoniecznie najważniejszym. Pacyfiści odnosili sukcesy polityczne wtedy, gdy udawało im się wykorzystać niechęć społeczeństwa do tradycyjnego elitarnego modelu rządzenia, nie uwzględniającego szerokiej partycypacji społecznej w podejmowaniu decyzji, oraz obaw przed uwikłaniem w wojny prowadzone przez USA (np. w Wietnamie). Kiedy synergia tych trzech czynników nie była zapewniona (jak na przykład w wypadku zacieśniania współpracy wojskowej z USA w drugiej połowie lat siedemdziesiątych), rząd był w stanie przeprowadzić kontrowersyjne zmiany bez narażania się na konfrontację z opinią publiczną.

W okresie powojennym w Japonii ukształtował się tzw. ,system 1955 roku”, którego determinującą charakterystyką była dominacja Partii Liberalno-Demokratycznej (ang. Liberal-Democratic Party - LDP), która nieprzerwanie sprawowała rządy w latach 1955-1993 (a następnie 1994-2009, w formule rządów koalicyjnych). W efekcie system partyjny Cesarstwa można nazwać jako 1,5 partyjny, co podkreśla słabość opozycji oraz uprzywilejowaną pozycję partii rządzącej. $Z$ punktu widzenia formułowania i wykonania polityki bezpieczeństwa istotne były dwie cechy tego układu, tj. dwubie-

9 Y. Izumikawa, Explaining Japanese Antimilitarism Normative and Realist Constraints on Japan's Security Policy, „International Security” 2010, No. 2, Vol. 35. 
gunowy układ sił politycznych oraz rozproszony system decyzyjny w ramach partii rządzącej.

Można uznać, iż układ sił między głównymi stronnictwami politycznymi był wewnętrznym odbiciem dwubiegunowego ładu międzynarodowego, w którym funkcjonowała ówczesna Japonia. Konserwatywna partia rządząca (opowiadająca się za utrzymaniem sojuszu z USA oraz funkcjonowaniem Sił Samoobrony w ograniczonej formule) utrzymywała stałą przewagę nad lewicową opozycją (postulującą neutralność i całkowite rozbrojenie). Jednak pozycja socjalistów i komunistów, tak w parlamencie, jak i wynikająca z poparcia wpływowych środowisk opiniotwórczych, była na tyle silna, iż rządzący nie mogli ignorować ich stanowiska, także (a może nawet przede wszystkim) w zakresie polityki zagranicznej i bezpieczeństwa. Jednocześnie LDP była partią mocno zróżnicowaną wewnętrznie, podzieloną na frakcje i tzw. „plemiona polityczne" ${ }^{10}$. Ostateczny kształt ustawodawstwa, jak i bieżącej polityki rządu był najczęściej wynikiem długotrwałych konsultacji wewnątrzpartyjnych i efektem kompromisu między różnymi frakcjami.

Ogólnie rzecz biorąc trzeba zauważyć, iż przez większość okresu powojennego w Japonii występował deficyt silnego przywództwa, tak potrzebnego dla prowadzenia efektywnej polityki zagranicznej i bezpieczeństwa. Wynikało to w znacznej mierze z faktu, iż kolejni premierzy byli w praktyce ,zakładnikami' polityki frakcyjnej w ramach partii rządzącej. Istotnym czynnikiem była również szczególna pozycja i wpływy zawodowych urzędników służby cywilnej. Pozycja elit biurokratycznych w Japonii jest znacznie silniejsza niż w innych rozwiniętych demokracjach. Starannie dobrane kadry urzędnicze stanowiły o efektywności japońskiego państwa i wysiłków modernizacyjnych od czasów rewolucji Meiji. Kariera w służbie cywilnej nadal pozostaje źródłem znacznego prestiżu i przyciaga najwybitniejszych absolwentów najważniejszych japońskich uniwersytetów. Rola profesjonalnej biurokracji w formułowaniu i egzekwowaniu polityki państwa jest tak znaczna, iż niektórzy mówią nawet o sytuacji, w której „LDP panowała, ale to biurokracja naprawdę rządziła”"11. Typowy dla tego okresu był oddolny system podejmowania decyzji w ramach władzy wykonawczej. Wobec częstych zmian na stanowiskach obsadzanych przez polityków (warto przypomnieć, iż od 1945 r. Japonia miała 32 premierów, a zmiany na stanowiskach ministerialnych były jeszcze częstsze), polityka państwa była formułowana przede wszystkim przez aparat biurokratyczny. Proces decyzyjny zazwyczaj rozpoczynał się na poziomie komórek organizacyjnych ministerstw i dopiero po zakończeniu konsultacji na poziomie biurokracji trafiał pod obrady gremiów politycznych (partyjnych i rządowych), które najczęściej po prostu zatwierdzały decyzje podjęte przez urzędników ${ }^{12}$.

W efekcie przytoczonych powyżej uwarunkowań powstał kompleksowy system ograniczeń blokujący możliwości prowadzenia aktywnej polityki obronnej oraz

10 Japan's International Relations, op. cit., s. 58-59.

11 Ch. Johnson, The State and Japanese Grand Strategy, w: The Domestic Bases of Grand Strategy, eds. R. Rosecrance, A. A. Stein, Ithaca 1993, s. 216. Cyt. za: M. M. Mochizuki, Japan's Long Transition: The Politics of Recalibrating Grand Strategy, w: Strategic Asia 2007-08 Domestic Political Change and Grand Strategy, eds. A. J. Telliis, M. Wills, s. 80.

12 T. Shinoda, Koizumi Diplomacy: Japan's Kantei Approach to Foreign and Defense Affairs, Seattle 2007, s. 21-25. 
znaczącej rozbudowy sił zbrojnych, a zatem gwarantujący realizację koncepcji „pacyfistycznego państwa handlowego". Opierał się na trzech filarach: regulacjach konstytucyjnych (art. 9 Konstytucji oraz jego oficjalna interpretacja), dodatkowych ograniczeniach prawno-politycznych nałożonych na politykę obronną oraz rozbudowanym systemie cywilnej kontroli nad siłami zbrojnymi. Najważniejszy fundament powojennej polityki bezpieczeństwa Japonii stanowi art. 9 Konstytucji Cesarstwa z 3.11.1946 roku, zgodnie z którym:

„Naród japoński, dążąc szczerze do międzynarodowego pokoju opartego na sprawiedliwości i porządku, wyrzeka się na zawsze wojny jako suwerennego prawa narodu, jak również użycia lub groźby użycia siły jako środka rozwiązywania sporów międzynarodowych.

Dla osiagnięcia celu określonego w poprzednim ustępie nie będą nigdy utrzymywane siły zbrojne lądowe, morskie i powietrzne ani inne środki mogące służyć wojnie. Nie uznaje się prawa państwa do prowadzenia wojny"13.

Powyższe zapisy wyrażają esencję tożsamości Japonii jako państwa pacyfistycznego. Jednak ich interpretacja niemal od samego początku budziła istotne kontrowersje. Dosłowne odczytanie regulacji konstytucyjnych prowadzi do wniosku, iż samo posiadanie sił zbrojnych (nawet o wybitnie defensywnym charakterze) jest nielegalne. Mimo to, japońscy przywódcy zdecydowali się w 1954 r. na powołanie Sił Samoobrony, czyli sił zbrojnych pod każdym względem oprócz nazwy. Decyzja ta była motywowana świadomością konieczności posiadania minimalnego potencjału obronnego, oraz (w znacznej mierze) naciskami amerykańskiego sojusznika. W oczywisty sposób pojawiła się kwestia konstytucyjności istnienia nowej formacji. Ponieważ Sąd Najwyższy odmówił rozpatrzenia tej sprawy, zadanie interpretacji zapisów art. 9 powierzono Biuru Legislacyjnemu Gabinetu (ang. Cabinet Legislation Bureau - CLB). Instytucja ta uważana jest za najpotężniejszy organ biurokratyczny w Japonii. Wchodzi on w skład administracji premiera i jego podstawowym zadaniem jest orzekanie o zgodności aktów prawnych oraz szerzej polityki rządu z konstytucją. Co więcej kontrola ta jest dokonywana już na etapie prac legislacyjnych, a nie post fatum (jak przyjęto w sądownictwie konstytucyjnym innych państw). Orzeczenia CLB są traktowane jako oficjalna wykładnia prawa stosowana przez rząd. Stąd interpretacja zapisów art. 9 była i jest wykładnią tego co jest dozwolone w japońskiej polityce obronnej.

Od początku jednak orzecznictwo CLB w tej kwestii było przedmiotem politycznych nacisków i manipulacji. Premier Yoshida pragnął takiej interpretacji, jaka służyłaby celom jego strategii, tzn. dopuszczającej funkcjonowanie Sił Samoobrony, ale ograniczonych co do potencjału i możliwości uczestnictwa w operacjach sojuszniczych. Jego życzeniom stało się zadość dzięki orzeczeniu Biura z 1952 r., w myśl, którego konstytucja zabrania posiadania potencjału wojennego (jap. senryoku) tzn.: ,[...] sił o wyposażeniu i organizacji umożliwiających prowadzenie nowoczesnej wojny... Określenie co stanowi potencjał wojenny wymaga konkretnego osądu, uwzględniającego czasowe i przestrzenne środowisko omawianego państwa... Niekonstytucyjnym

13 Konstytucja Japonii z 3 listopada 1946 r. (thumaczenie prof. Teruji Suzuki), http://www.pl.emb-japan.go.jp/relations/konstytucja.htm (27.01.2011). 
nie jest, ani utrzymywanie zdolności, które nie przekraczają progu potencjału wojennego, ani ich użycie dla obrony narodu przed bezpośrednią inwazją" ${ }^{14}$.

Jak zatem widać, określenie co stanowi potencjał wojenny, a co „nie przekracza jego progu" stało się kwestią uznaniową, zależną od konkretnych okoliczności i zapotrzebowania politycznego. W praktyce stopniowo doprowadziło to do sytuacji, w której dozwolony był praktycznie każdy system uzbrojenia, który można było określić jako defensywny (w skrajnych interpretacjach nawet broń nuklearna). Kolejnym problemem prawnym była kwestia dopuszczalności uczestnictwa Japonii w zbiorowej samoobronie (będącej prawem zagwarantowanym w art. $51 \mathrm{KNZ}$ ). Japońscy decydenci próbowali obejść ten problem rozróżniając „zbiorową samoobronę" (użycie siły w obronie sojusznika) oraz ,zbiorowe bezpieczeństwo” (szeroki wachlarz działań politycznych, ekonomicznych i militarnych podejmowanych w ramach wielostronnej współpracy na forum organizacji międzynarodowych), jednocześnie akceptując drugą formułę. Ostatecznie CLB orzekło, iż zapisy KNZ dają Japonii prawo do zbiorowej samoobrony, jednak na mocy zapisów konstytucyjnych nie może ona z niego korzystać. Taka konstrukcja prawna, rygorystycznie interpretowana, prowadziłaby do kuriozalnej sytuacji, w której Siły Samoobrony nie mogłyby przyjść z pomocą amerykańskiemu okrętowi wojennemu, zaatakowanemu w trakcie obrony Japonii ${ }^{15}$.

Stopniowo na politykę obronną nakładano dodatkowe ograniczenia polityczne, niezależne od zapisów konstytucyjnych. Dotyczyły one zbrojeń nuklearnych, eksportu uzbrojenia i sprzętu wojskowego, pokojowego wykorzystania przestrzeni kosmicznej oraz wielkości wydatków obronnych. W roku 1967 premier Eisaku Sato ogłosił tzw. trzy zasady nie-nuklearne, stanowiące iż Japonia nie będzie wytwarzać, posiadać, ani tolerować na swoim terytorium broni nuklearnej. Stanowią one jeden z filarów japońskiej polityki nuklearnej do dziś, co nie zmienia faktu, iż w czasie zimnej wojny, na mocy nieformalnych porozumień, tolerowano obecność amerykańskiej broni nuklearnej na terytorium Japonii.

W tym samym roku premier E. Sato ogłosił zakaz eksportu broni do trzech kategorii państw: komunistycznych, objętych sankcjami ONZ oraz uczestniczących w konfliktach zbrojnych (lub znajdujących się na granicy zaangażowania w takie konflikty). W latach siedemdziesiątych premier Takeo Miki rozszerzył ten zakaz zarówno podmiotowo (na wszystkie państwa) jak i przedmiotowo (na wszelki sprzęt wojskowy i jego elementy). Tym samym ostatecznie mocno ograniczono możliwości rozwoju japońskiego przemysłu zbrojeniowego jako branży eksportowej. W 1969 roku Diet przyjął rezolucję o pokojowym wykorzystaniu przestrzeni kosmicznej. Gabinet premiera Mikiego sformalizował również górny limit wydatków na obronę na poziomie $1 \%$ PKB. Biorąc pod uwagę wielkość japońskiego PKB (do niedawna japońska gospodarka zajmowała drugie miejsce na świecie pod względem nominalnego PKB) nie musiało to koniecznie oznaczać niskiego nominalnego poziomu wydatków, jednak należy

14 A. Nakamura, Sengo Seiji ni Yureta Kenpo Kyujo [Article 9 That Shook Postwar Politics], Tokio 2001, s. 99. Cyt za: R. J. Samuels, Securing Japan Tokyo's Grand Strategy and the Future of East Asia, New York 2008, s. 46.

${ }_{15}$ Na podstawie: R. J. Samuels, Securing Japan: Tokyo's Grand Strategy and the Future of East Asia, op. cit., s. 45-49. 
pamiętać, iż w praktyce realnie przydzielane budżety regularnie zawierały sumy niższe od $1 \% \mathrm{PKB}^{16}$.

Kolejne istotne ograniczenie polityki bezpieczeństwa stanowił bardzo rygorystyczny system cywilnej kontroli nad siłami zbrojnymi. Szczególna rola norm antymilitarystycznych w powojennej kulturze politycznej (omówiona już wcześniej) oraz negatywne doświadczenia z czasów przedwojennych (kiedy wojsko zdominowało cały system polityczny) przyczyniły się do stworzenia mechanizmów kontrolnych znacznie bardziej rygorystycznych niż spotykane w większości państw demokratycznych. Do 2007 r. nie istniało samodzielne ministerstwo obrony. Jego funkcję pełniła Agencja Obrony (ang. Japan Defence Agency - JDA) wchodząca w skład administracji premiera. Wpływy i pozycja tej instytucji w kontekście międzyresortowych sporów i rozgrywek były bardzo słabe, przede wszystkim w porównaniu do wpływowych resortów finansów i spraw zagranicznych. Wynikało to po części z faktu, iż najważniejsze stanowiska w ramach Agencji regularnie obsadzano urzędnikami oddelegowanymi z innych ministerstw i agencji rządowych. Tym samym praca w Agencji Obrony nie oferowała atrakcyjnej ścieżki kariery dla młodych i ambitnych urzędników.

Kolejną cechą charakterystyczną tego systemu było niemal całkowite wyłączenie wojskowych z procesu planowania i programowania polityki obronnej. Biorąc pod uwagę, iż odpowiedzialni za ten proces cywilni urzędnicy w większości mieli bardzo ograniczone doświadczenie i wiedzę w zakresie spraw wojskowych efektywność całego procesu zawsze budziła głębokie wątpliwości. Można to zaobserwować na przykładzie zamówień uzbrojenia i sprzętu wojskowego, które były determinowane raczej przez interesy przemysłu obronnego (w zakresie utrzymania produkcji i rozwoju zaplecza technologicznego) niż wymogami strategii wojskowej i operacyjnymi potrzebami sił zbrojnych. Biorąc pod uwagę niewielką liczebność Sił Samoobrony oraz zakaz eksportu uzbrojenia, nie może dziwić fakt, iż cena jednostkowa zamawianego sprzętu była bardzo wysoka. Nadzwyczaj złożona i problematyczna była również kwestia łańcucha dowodzenia siłami zbrojnymi. Trzeba tu zaznaczyć, iż do 2003 roku w Japonii nie istniały przepisy prawne określające zasady funkcjonowania władzy państwowej i sił zbrojnych w warunkach sytuacji kryzysowej. Nawet w sytuacji zagrożenia atakiem miała obowiązywać standardowa, pokojowa procedura decyzyjna, w której premier wydaje rozkazy operacyjnego użycia wojsk, które następnie są przekazywane za pośrednictwem dyrektora generalnego Agencji Obrony i szefów rodzajów Sił Samoobrony. Jednak za każdym razem wymagana jest akceptacja rozkazów przez parlament i Radę Bezpieczeństwa Narodowego, co ogromnie ogranicza elastyczność całego procesu decyzyjnego oraz zdolność do szybkiego reagowania na zagrożenia. Taki stan rzeczy był wielokrotnie przedmiotem krytyki ze strony dowódców wojskowych. Jednak najczęściej publiczne wygłaszanie takich opinii kończyło się politycznym skandalem i szybkimi dymisjami zainteresowanych oficerów ${ }^{17}$.

Efektem omówionych powyżej ograniczeń było stworzenie sytuacji, w której pokojowy charakter polityki państwa był skutecznie zagwarantowany, ale równocześnie zdolność Cesarstwa do skutecznej obrony przed agresją była mocno wątpliwa.

${ }_{16}^{16}$ K. B. Pyle, op. cit., s. 250-255.

17 Na podstawie: R. J. Samuels, op. cit., s. 49-57. 
Japońscy decydenci zdawali sobie doskonale sprawę, iż w takim układzie ich państwo niejako wyrzekło się zdolności do realizacji jednej ze swych podstawowych funkcji, tzn. zapewnienia obrony przed zagrożeniami zewnętrznymi. Taki stan rzeczy był tolerowany, gdyż obowiązek zapewnienia Cesarstwu bezpieczeństwa przyjął na siebie potężny sojusznik - Stany Zjednoczone. Sojusz ten do dziś stanowi jeden z najważniejszych czynników determinujących japońską politykę bezpieczeństwa. Zawarty między zażartymi wrogami, krótko po zakończeniu II wojny światowej był konsekwencją zimnowojennego porządku świata ${ }^{18}$. Początkowo Amerykanie dążyli poprzez okupację do całkowitego rozbrojenia Japonii i uczynienia z niej państwa słabego, które nie stanowiłoby już żadnego zagrożenia. Jednocześnie wprowadzono ambitny program reform wewnętrznych, które miały przekształcić japońskie państwo, gospodarkę i społeczeństwo według wzorców amerykańskich. Jednak nasilająca się pod koniec lat czterdziestych konfrontacja zimnowojenna skłoniła okupantów do zmiany koncepcji. O ile w początkowym okresie okupacji (1945-1947) obawy USA koncentrowały się na możliwości odrodzenia się japońskiego militaryzmu, to w drugim etapie (1948-1951) główną troską stała się podatność Cesarstwa na wpływy komunistyczne.

Japonia odgrywała kluczowe znaczenie w amerykańskiej zimnowojennej strategii wobec Azji ze względów geopolitycznych oraz gospodarczych. Posiadanie baz wojskowych na archipelagu położonym strategicznie u wybrzeży Azji Północno-Wschodniej zapewniało możliwość kontroli dostępu do zachodniego basenu Pacyfiku oraz szlaków morskich wiodących do wybrzeży dwóch wrogich potęg kontynentalnych, ZSRR i ChRL. Jednocześnie Japonia jako jedyne wówczas państwo uprzemysłowione regionu mogła być cennym nabytkiem dla każdego z rywalizujących ze sobą bloków. Jak zauważył George Kennan, dopóki zdobycze komunistów w Azji ograniczały się do zacofanych państw o gospodarce rolniczej (takich jak ChRL czy Korea Północna) potencjał bloku wschodniego nie ulegał istotnemu wzmocnieniu ${ }^{19}$. Jednak gdyby udało się opanować państwo z zapleczem przemysłowym, wyedukowaną siłą roboczą oraz względnie nowoczesnymi technologiami, sytuacja byłaby diametralnie inna. Wobec tych wszystkich czynników władze USA doszły do wniosku, iż utrzymanie Japonii we własnym obozie ma kluczowe znaczenie dla powodzenia polityki powstrzymywania komunizmu w Azji.

Dla japońskich przywódców sojusz również jawił się jako nadzwyczaj atrakcyjna opcja. Ich priorytetem było zapewnienie bezpieczeństwa państwa oraz korzystnych warunków dla odbudowy gospodarczej. Obu celom służyła ponowna integracja ze społecznością międzynarodową. Zdawano sobie sprawę, iż Japonia jest obiektem głębokiej nieufności, czy wręcz otwartej wrogości w całym regionie, co w naturalny sposób wynikało z wydarzeń II wojny światowej. Względna normalizacja stosunków, na której zależało decydentom Cesarstwa (przede wszystkim w zakresie relacji handlowych) siłą rzeczy musiała być procesem długotrwałym i skomplikowanym, a ewentualna remilitaryzacja mogłaby ją całkowicie przekreślić. Yoshida doskonale zdawał

18 Szerokie omówienie okoliczności zawarcia sojuszu w: R. J. Samuels, op. cit., s. 39-41, oraz K. B. Pyle, op. cit., s. 221-238.

19 Patrz: D. Halberstam, The Coldest Winter America and the Korean War, New York 2007, s. $195-196$. 
sobie sprawę z tego, jak cenna dla Amerykanów jest Japonia i bezwzględnie to wykorzystał dążąc do zawarcia porozumienia na korzystnych dla niej warunkach. USA miały wziąć na siebie główny ciężar zapewnienia bezpieczeństwa archipelagu, pozwalając tym samym Japończykom na utrzymywanie wydatków wojskowych na niskim poziomie. Jednocześnie poprzez sojusz z supermocarstwem oraz włączenie w jego sieć sojuszy regionalnych Japonia zyskiwała silne wsparcie na drodze do integracji z nowym powojennym systemem międzynarodowym.

Komplementarne potrzeby i interesy obu partnerów szybko zaowocowały podpisaniem Traktatu bezpieczeństwa ( 8 września 1951 r.). Jego istotą było japońskie zobowiązanie do przyjęcia na swym terytorium amerykańskich baz wojskowych, w zamian za gwarancje bezpieczeństwa. Należy jednak odnotować, iż traktat był rażąco nierówny. Nie zawiera on wprost sformułowanego zobowiązania USA do obrony Japonii w wypadku agresji (jednak taką gwarancję można by wyprowadzić z preambuły i bez wątpienia stanowiła ona część „ducha”, jeżeli nie „litery” traktatu). Od początku było jasne, iż istotnym (o ile nie najważniejszym) zadaniem sił amerykańskich będzie „utrzymywanie międzynarodowego pokoju i bezpieczeństwa na Dalekim Wschodzie”. Zapisy traktatowe pozwalały na wykorzystanie wojsk amerykańskich do stłumienia rozległych zamieszek i wewnętrznych niepokojów (na prośbę rządu japońskiego) inspirowanych przez siły zewnętrzne. Oddziały stacjonujące na archipelagu mogły zostać wysłane do walki w dowolnym punkcie Dalekiego Wschodu bez żadnej konsultacji z państwem przyjmującym ${ }^{20}$. Co więcej, Okinawa wciąż pozostawała pod władzą amerykańskiej administracji wojskowej (japońską suwerenność nad wyspą przywrócono dopiero w 1972 roku). Konsekwencją traktatu było również porozumienie o statusie wojsk amerykańskich w Japonii, które zapewniało obcym wojskom daleko posunięte przywileje (związane głównie z eksterytorialnością).

W roku 1960, dzięki staraniom rządu Nobusuke Kishiego udało się doprowadzić do renegocjacji traktatu ${ }^{21}$. W tym roku podpisano nowy Traktat o Wzajemnej Współpracy i Bezpieczeństwie. Podstawowe postanowienia pozostały niezmienione (chociaż zobowiązania USA do obrony Japonii zostały nieco wyraźniej sformułowane), jednak wyeliminowano zapis o możliwości użycia wojsk amerykańskich do thumienia rozruchów wewnętrznych i wprowadzono możliwość konsultacji w zakresie implementacji postanowień traktatu (w tym zapewne udziału wojsk stacjonujących na archipelagu w operacjach poza terytorium Japonii). Traktat ten w niezmienionej formie pozostaje w mocy do dziś.

Praktycznie przez cały okres zimnej wojny sojusz pozostawał silny i dobrze służył interesom obu partnerów. USA mogły wykorzystywać japońskie bazy jako „niezatapialny lotniskowiec”, a japońska gospodarka rozwijała się pod „tanią ochroną” amerykańskiej potęgi militarnej. Analizując stan partnerstwa należy pamiętać o tym, iż w każdym sojuszu partnerzy żywią dwie zasadnicze obawy: opuszczenia przez sojusz-

20 Security Treaty Between the United States and Japan, w: Japan's International Relations, op. cit., s. 561-562.

21 Patrz: Japan's International Relations, op. cit., s. 148-149, oraz Treaty of Mutual Cooperation and Security Between The United States and Japan, w: Japan's International Relations, op. cit., s. $563-564$. 
nika lub uwikłania w prowadzone przez niego konflikty ${ }^{22}$. W okresie zimnej wojny dla strony japońskiej niebezpieczeństwo opuszczenia było znikome. $\mathrm{Z}$ omówionych wcześniej powodów Japonia była zbyt cenna i zajmowała uprzywilejowaną pozycję w amerykańskiej strategii regionalnej. Większym niebezpieczeństwem dla Japonii było uwikłanie w wojny prowadzone przez USA. Amerykanie oczekiwali od swego sojusznika wsparcia działań w Korei i Wietnamie oraz szerzej większego wkładu w regionalne bezpieczeństwo (co zostało wyraźnie wyartykułowane w tzw. doktrynie Guam ogłoszonej przez prezydenta R. Nixona w 1969 roku). Jednak japońskim przywódcom udawało się uniknąc dalej idących zobowiązań sojuszniczych, w znacznej mierze dzięki powoływaniu się na zapisy art. 9 Konstytucji, jak i wielki opór opinii publicznej wobec wszelkich przejawów militaryzmu, a nawet wobec samego sojuszu (czego dobitnym dowodem były masowe demonstracje przeciwników rewizji traktatu sojuszniczego w 1960 roku).

Po stronie USA ryzyko uwikłania faktycznie nie istniało. Kierując się doktryną Yoshidy Japonia nie była skłonna do eskalacji jakiegokolwiek konfliktu międzynarodowego do poziomu użycia siły militarnej. Opuszczenie również wydawało się mało prawdopodobne. Decydując się na podpisanie traktatów sojuszniczych Japonia niemal całkowicie oparła swe bezpieczeństwo (i szerzej całą politykę zagraniczną) na przymierzu z USA. W okresie zimnej wojny praktycznie nie było żadnej innej realnej alternatywy. Postulaty krytyków sojuszu były nierealistyczne. Pełne usamodzielnienie się w zakresie polityki obronnej byłoby niezwykle kosztowne i wzbudziłoby jeszcze większą nieufność, a nawet wrogość w regionie, prowadząc do izolacji. Rozbrojenie i neutralność W warunkach zimnowojennego systemu regionalnego również niosło ze sobą wielkie ryzyko, wobec zagrożenia ze strony ZSRR, Korei Północnej czy ChRL.

Problemem dla USA była jednak japońska niechęć do uczestnictwa w zbiorowej samoobronie. Jak stwierdził sam Shigeru Yoshida, „ci, którzy uważają, iż amerykańsko-japoński Traktat Bezpieczeństwa zaprojektowano do prowadzenia wojny są w błędzie" ${ }^{23}$. Wobec tego amerykańskie wojska stacjonujące w Japonii w wypadku sytuacji kryzysowej nie mogły liczyć na daleko idące wsparcie ze strony Sił Samoobrony. O prowadzeniu wspólnych działań bojowych w zasadzie nie mogło być mowy. W przeciwieństwie do innych układów sojuszniczych (jak np. NATO czy sojusz z Republiką Korei) nie istniały efektywne mechanizmy współpracy operacyjnej między wojskami amerykańskimi i japońskimi. Brakowało wspólnego planowania kryzysowego, ćwiczeń czy mechanizmów koordynacji działań. Stąd użyteczność Sił Samoobrony dla sojusznika w wypadku wybuchu wojny mogła się ograniczyć jedynie do wsparcia logistycznego i udostępniania baz. W sposób zrozumiały rodziło to oskarżenia po stronie amerykańskiej o tzw. „tanią jazdę” na amerykańskich gwarancjach bezpieczeństwa i ciagłe wezwania do bardziej równego podziału obowiązków w ramach sojuszu. Nie można jednak pominąć faktu, iż ta nierównowaga była częścią oryginalnej amerykańskiej koncepcji sojuszu. Miał on stanowić swoisty „korek od butelki” powstrzymujący

22 N. Bisley, Securing the „Anchor of Regional Stability”? The Transformation of the US-Japan Alliance and East Asian Security, „Contemporary Southeast Asia” 2008, Vol. 30, No. 1, s. 86-87.

23 S. Yoshida, Sekai to Nihon [The World and Japan], Tokio 1963, s. 165. Cyt. za: R. J. Samuels, op. cit., s. 40 . 
Japonię przed remilitaryzacją ${ }^{24}$. Miało to służyć z jednej strony eliminacji ewentualnego zagrożenia ze strony Cesarstwa, a z drugiej stabilizacji regionalnej wobec powszechnej nieufności pod adresem Japonii. Dowodem sukcesu tej polityki jest akceptacja korzyści z niej płynących nawet przez ChRL, w którą (między innymi) pierwotnie sojusz był wymierzony ${ }^{25}$.

W latach siedemdziesiątych i osiemdziesiątych rozpoczął się jednak proces powolnych zmian w japońskiej polityce bezpieczeństwa, prowadzących w stronę większej efektywności Sił Samoobrony oraz ich bliższej współpracy z siłami sojuszniczymi. Motywację dla tego procesu stanowiła obawa przed osłabieniem amerykańskich gwarancji bezpieczeństwa wypływająca z zasad doktryny Nixona oraz ogólnego osłabienia pozycji USA w latach siedemdziesiątych. W późniejszym okresie polityka ta wpisywała się w kontekst tzw. „drugiej zimnej wojny” oraz wiążącego się z nią wzrostu zagrożenia ze strony ZSRR. Efektem było przyjęcie pierwszego Zarysu Programu Obrony Narodowej (ang. National Defence Program Outline - NDPO) w 1976 r. oraz (również po raz pierwszy) Wytycznych Współpracy Obronnej (ang. Guidelines for US-Japan Defence Cooperation) w 1978 r. Dokumenty te tworzyły podstawy strategii obronnej (z określeniem niezbędnego poziomu potencjału obronnego) oraz współpracy wojskowej z USA.

$\mathrm{Na}$ przełomie lat siedemdziesiątych i osiemdziesiątych miały miejsce pierwsze wspólne ćwiczenia Sił Samoobrony z ich amerykańskimi odpowiednikami. Przełomowa była również decyzja rządu Zenko Suzukiego, o tym, iż Morskie Siły Samoobrony będą patrolować morskie szlaki komunikacyjne w odległości do 1000 mil morskich od wybrzeży Japonii. Najaktywniejszym propagatorem bardziej aktywnej polityki bezpieczeństwa w tamtym okresie był premier Yasuhiro Nakasone (pełnił urząd w latach 1982-1987). Należał on do rewizjonistycznego skrzydła LDP i wcześniej jako dyrektor generalny Agencji Obrony (w latach 1970-1971) promował koncepcję autonomicznej obrony. Jako premier dążył do osłabienia ograniczeń nałożonych na politykę zagraniczną i obronną w okresie powojennym. Nakasone wprowadził nowy styl silnego przywództwa i zdecydowanie popierał politykę prezydenta Ronalda Reagana wobec ZSRR. Jednak ze względu na wewnętrzne uwarunkowania polityczne nie udało mu się trwale zreformować japońskiej polityki bezpieczeństwa. Jego dokonania w tej materii w znacznej mierze ograniczyły się do odważnej (i budzącej kontrowersje w polityce wewnętrznej) retoryki. Trzeba jednak uczynić wyjątek od tej oceny w odniesieniu do przeforsowania przez jego gabinet zacieśnienia współpracy przemysłowej z USA w dziedzinie technologii wojskowych (przejawiających się m.in. we włączeniu Japonii do amerykańskiego programu obrony przeciwrakietowej), które wyraźnie osłabiły ograniczenia w zakresie eksportu sprzętu wojskowego ${ }^{26}$.

Ostateczne zasadnicze kierunki japońskiej polityki bezpieczeństwa pozostały stałe do samego końca zimnej wojny. Nadzwyczajne sukcesy gospodarcze, przyczyniły się do powstania opinii o Japonii jako modelu „superpaństwa” lepiej dostosowanego do wymogów nowej epoki, w której rola siły w stosunkach międzynarodowych miała stale

\footnotetext{
24 Patrz: Japan's International Relations, op. cit., s. 145.

25 Patrz: K. B. Pyle, op. cit., s. 321-322.

${ }^{26}$ Japan's International Relations, op. cit., s. 152-156.
} 
maleć. Należy jednak pamiętać, iż rozwój Cesarstwa jako „,państwa moratorium” był możliwy w znacznej mierze dzięki ochronie potęgi militarnej USA oraz względnej stabilności ładu zimnowojennego w Azji.

\section{POLITYKA BEZPIECZEŃSTWA JAPONII PO ZAKOŃCZENIU ZIMNEJ WOJNY - POWOLNA DROGA DO „NORMALNOŚCI”}

$\mathrm{Na}$ przełomie lat osiemdziesiątych i dziewięćdziesiątych środowisko, w którym była kształtowana i wykonywana japońska polityka bezpieczeństwa (zarówno międzynarodowe, jak i wewnętrzne) uległo gwałtownemu przeobrażeniu. Radykalna przebudowa ładu międzynarodowego (tak w skali globalnej, jak i regionalnej) w połączeniu z istotnymi zmianami wewnątrz systemu politycznego Cesarstwa stworzyły warunki, w których reforma (lub zupełne zarzucenie) doktryny Yoshidy stały się nie tylko możliwe, ale również pożądane. W pierwszej połowie lat dziewięćdziesiątych japońscy decydenci zostali skonfrontowani z koniecznością reakcji na dwa poważne kryzysy międzynarodowe, które można uznać za uosobienie nowych wyzwań dla bezpieczeństwa ich państwa w nowej pozimnowojennej rzeczywistości międzynarodowej. Pierwszy z nich był efektem inwazji Iraku na Kuwejt w 1990 roku, drugi dotyczył północnokoreańskiego programu nuklearnego (I koreański kryzys nuklearny z lat 1993-1994). Okazało się, iż próby zmierzenia się $\mathrm{z}$ nową sytuacją $\mathrm{w}$ oparciu o tradycyjne wzorce postępowania zakorzenione w doktrynie Yoshidy zakończyły się niepowodzeniem. Tym samym oba kryzysy stały się silnym bodźcem, dla uruchomienia procesu ewolucyjnych zmian w polityce bezpieczeństwa Cesarstwa, które w ciąu następnych dwóch dekad przyniosły zgoła rewolucyjne efekty. Warto najpierw przybliżyć treść tego procesu, aby następnie wyjaśnić jego przyczyny i skutki.

Kiedy Stany Zjednoczone budowały międzynarodową koalicję, która miała na celu wyzwolenie Kuwejtu spod irackiej okupacji, wyrażano silne oczekiwania odnośnie wkładu Japonii w to przedsięwzięcie. Uznawano, iż jedno z najlepiej rozwiniętych gospodarczo państw świata, którego bezpieczeństwo energetyczne było zależne od dostaw ropy z Zatoki Perskiej uzna swą współodpowiedzialność za zapewnienie międzynarodowego pokoju i bezpieczeństwa. Okazało się jednak, iż japońskie elity, skrępowane ograniczeniami konstytucyjnymi i (w znacznie większym stopniu) brakiem politycznej woli zmiany prowadzonej z powodzeniem od ok. 40 lat polityki, okazały się zupełnie nieprzygotowane do szybkiej reakcji na kryzys. Propozycje udziału Sił Samoobrony w działaniach podejmowanych przez międzynarodową koalicję w Zatoce Perskiej zostały skutecznie zablokowane przez prawne interpretacje art. 9 oraz spory międzyresortowe.

Zdaniem wielu zagranicznych i krajowych obserwatorów, rząd japoński znalazł się w stanie paraliżu decyzyjnego, niezdolny (mimo ambitnych deklaracji) do wyegzekwowania decyzji o zaangażowaniu w operację prowadzoną z mandatu ONZ. Ostatecznie Japonia wniosła w tą operację znaczy wkład finansowy (w wysokości 13 mld dolarów), a po zakończeniu operacji bojowych, okręty Morskich Sił Samoobrony uczestniczyły w oczyszczaniu Zatoki Perskiej z min. Zagraniczni partnerzy (w tym zwłaszcza USA) nie docenili jednak tych gestów i powszechnie krytykowali Japonię za 
korzystanie z dobrodziejstw międzynarodowego pokoju i bezpieczeństwa, bez wnoszenia żadnego wkładu w ich utrzymywanie. Praktycznie identyczny schemat powtórzył się w latach 1993-1994, kiedy to z powodu północnokoreańskiego kryzysu nuklearnego przez pewien czas za realną uznawano groźbę wybuchu wojny na Półwyspie Koreańskim. Okazało się, iż w takim wypadku Japonia byłaby niezdolna do zapewnienia nawet najbardziej podstawowego wsparcia siłom amerykańskim operującym z jej terytorium. Wzbudziło to zrozumiałą frustrację i oburzenie w Stanach Zjednoczonych ${ }^{27}$.

Wydarzenia te uświadomiły japońskim przywódcom konieczność dostosowania strategii bezpieczeństwa do nowej rzeczywistości oraz fakt, iż zapewnienie bezpieczeństwa narodowego w nowej rzeczywistości wymaga znacznie bardziej aktywnej polity$\mathrm{ki}^{28}$. Pierwszą istotną innowacją było przyjęcie w 1992 r. ustawy o Międzynarodowej Współpracy Pokojowej, która umożliwiła udział Sił Samoobrony w operacjach pokojowych ONZ. Tym samym podważono zakaz udziału sił zbrojnych w operacjach poza macierzystym terytorium, który wynikał z dotychczasowej, oficjalnej interpretacji art. 9 Konstytucji. Pierwszą misją pokojową, w której Siły Samoobrony uczestniczyły na mocy nowych regulacji była operacja ONZ w Kambodży. Udział sił japońskich w tym przedsięwzięciu uznano za znaczny sukces. Od tamtej pory japońscy żołnierze uczestniczyli w kilku operacjach ONZ.

Kolejnym ważnym krokiem było rozszerzenie ram współpracy sojuszniczej z USA. Negatywne doświadczenia kryzysu koreańskiego oraz wzrost napięć w regionalnym środowisku bezpieczeństwa (związanych m.in. z eskalacją napięć między ChRL a Tajwanem) doprowadziły sojuszników do wniosku o konieczności odnowienia i wzmocnienia zobowiązań oraz dostosowania formuły sojuszu do nowych warunków. Efektem tych zabiegów była Wspólna Deklaracja o Bezpieczeństwie: Sojusz dla XXI wieku, przyjęta przez prezydenta W. Clintona i premiera R. Hashimoto w kwietniu 1996 roku, oraz oparte na jej zapisach nowe Wytyczne dla Współpracy Obronnej przyjęte w 1997 roku. Najważniejszą ich konsekwencją było uznanie roli Cesarstwa w zapewnieniu bezpieczeństwa na „obszarach otaczających Japonię”, jak również powierzenie Siłom Samoobrony funkcji zapewnienia wsparcia tyłowego dla sił amerykańskich w wypadku kryzysu.

Najdalej idące reformy wprowadzono jednak w latach 2001-2003 w ramach zaangażowania w tzw. „wojnę z terroryzmem”. Chcąc udzielić oczekiwanego wsparcia sojusznikowi oraz dla uniknięcia błędów z poprzedniej dekady, rząd Junichiro Koizumiego zdecydował się na bezprecedensowe kroki. Jeszcze w 2001 roku podjęto decyzję o wysłaniu zespołu okrętów Morskich Sił Samoobrony na Ocean Indyjski w celu udzielenia wsparcia logistycznego siłom międzynarodowej koalicji prowadzącym interwencję w Afganistanie. Stanowiło to jawne naruszenie dotychczasowej interpretacji zapisów konstytucyjnych, jednak pod naciskiem premiera CLB wydało opinię o konstytucyjności regulacji ustawy o Specjalnych Środkach Antyterrorystycznych (która stanowiła prawną podstawę dla wysłania okrętów). Uznano, iż dopóki jednostki Sił Samoobrony

27 K. B. Pyle, op. cit., s. 290-296.

28 Szerzej: R. J. Samuels, op. cit., s. 87-107. 
znajdują się poza bezpośrednią strefą walk i nie uczestniczą w operacjach bojowych, działalność taka jest dopuszczalna.

Jeszcze poważniejszym krokiem był udział Lądowych Sił Samoobrony w misji stabilizacyjnej w Iraku. Mimo, iż decyzja ta budziła ogromne kontrowersje ostatecznie premier Koizumi i tym razem osiagnął swój cel. W latach 2003-2004 kilkuset japońskich żołnierzy stacjonowało w irackiej prowincji Smawah, gdzie uczestniczyli w ściśle niebojowych działaniach humanitarnych, przy rygorystycznych ograniczeniach w zakresie stosowania siły. W roku 2003 przyjęto również pakiet ustaw regulujących funkcjonowanie administracji państwowej i sił zbrojnych w sytuacjach kryzysowych, tworząc w końcu (prawie 50 lat po powstaniu Sił Samoobrony) efektywne podstawy prawne dla skutecznego przeciwstawienia się agresji. Na przestrzeni ostatniej dekady rozpoczęto również ambitny program budowy systemu obrony przeciwrakietowej (realizowany w ścisłej współpracy z USA), jak również zacieśniono współpracę z innymi regionalnymi sojusznikami Stanów Zjednoczonych (czego doskonałym przykładem jest porozumienie o współpracy wojskowej z Australią podpisane w 2007 roku).

\section{Przyczyny zmian}

Ewolucja japońskiej polityki bezpieczeństwa po zimnej wojnie jest efektem synergii trzech czynników: nowego międzynarodowego środowiska bezpieczeństwa, nacisków sojuszniczych oraz zmian systemie politycznym Cesarstwa. Chociaż wszystkie te trzy elementy niewątpliwie oddziaływały również w czasie zimnej wojny, to jednak jej zakończenie znacząco zmieniło ich charakter.

Zimnowojenne środowisko bezpieczeństwa Japonii było względnie stabilne i przewidywalne. Realne zagrożenie atakiem ze strony ChRL, Korei Północnej i ZSRR było stosunkowo niewielkie i jako takie było w Japonii postrzegane. Amerykańskie gwarancje bezpieczeństwa były wystarczającym zabezpieczeniem przed wszystkimi prawdopodobnymi zagrożeniami. Koniec zimnej wojny, który przyniósł stabilizację i wzrost poczucia bezpieczeństwa np. w Europie, w Azji zburzył w miarę stabilną strukturę ładu regionalnego i wprowadził nowe czynniki niepewności i potencjalnej niestabilności. Z punktu widzenia Japonii najważniejszymi wyzwaniami są agresywna polityka Korei Północnej oraz gwałtowny wzrost potegi Chin.

Postawa Korei Północnej wywarła największy wpływ na percepcję zagrożeń w Japonii, zarówno wśród elit, jak i w szerszych kręgach społecznych. Szczególnie silne wrażenie na opinii publicznej wywarła próba rakiety balistycznej Taepodong, która w 1998 roku przeleciała nad terytorium Japonii oraz oficjalne potwierdzenie przez władze KRL-D faktu uprowadzenia i więzienia obywateli japońskich (mieli oni szkolić agentów północnokoreańskiego wywiadu, tak aby jak najlepiej wtapiali się oni w japońskie społeczeństwo). Dla reżimu rządzącego KRL-D walka z japońską okupacją stanowi jeden z kluczowych mitów założycielskich. Stąd reżim północnokoreański często stosuje pod adresem Cesarstwa ostrą retorykę i niewybredne groźby. Często też na japońskich wodach terytorialnych operowały północnokoreańskie okręty szpiegowskie. W 2001 roku japońska Straż Wybrzeża po długim pościgu zatopiła jedną z tych jednostek (był to pierwszy przypadek użycia siły zbrojnej przez siły japońskie od 1945 roku). 
Obecnie agresywna polityka Korei Północnej oraz rozwijane przez to państwo programy nuklearny i rakietowy są uważane za najpoważniejsze zagrożenia dla bezpieczeństwa narodowego Japonii. Niektórzy komentatorzy uważają jednak, iż groźby te stały się użytecznym pretekstem dla tych spośród japońskich przywódców, którzy od dawna postulowali prowadzenie bardziej aktywnej polityki bezpieczeństwa. Nie da się ukryć, iż poczucie realnego zagrożenia ze strony Korei Północnej (materializującego się w postaci rakiet balistycznych przelatujących nad japońskim terytorium czy obecności północnokoreańskich jednostek szpiegowskich na japońskich wodach terytorialnych) w znacznym stopniu przyczyniło się do akceptacji przez opinię publiczną rozszerzenia zakresu misji i uprawnień Sił Samoobrony oraz coraz ściślejszej współpracy wojskowej z USA. W tym kontekście warto pamiętać, iż Półwysep Koreański jest tradycyjnie obszarem o szczególnym znaczeniu geopolitycznym z punktu widzenia interesów bezpieczeństwa Japonii. Ze względu na bliskość geograficzną, kontrola nad tym obszarem umożliwiłaby potencjalnemu przeciwnikowi wyprowadzenie ataku na archipelag Wysp Japońskich. Oczywiście mechanizm ten działa w obie strony - uzyskanie przyczółku na Półwyspie umożliwiło Japonii rozpoczęcie ekspansji w głąb kontynentu. Stąd Korea była tradycyjnie przedmiotem geopolitycznej rywalizacji ChRL i Japonii. Również współcześnie ta dynamika nie uległa całkowitemu zatarciu. Można zaryzykować tezę, iż z punktu widzenia obu potęg regionalnych, podział półwyspu na dwa państwa, z których jedno jest sojusznikiem Chin, a drugie co najmniej nie stanowi zagrożenia dla Japonii przyczynia się do stabilizacji tego układu regionalnego.

Pomimo iż Korea Północna stanowi obecnie najpoważniejsze, realne wyzwanie dla polityki zagranicznej i bezpieczeństwa Japonii, to najważniejszym problemem w perspektywie długofalowej jest określenie relacji z największą potęgą regionalną tj. ChRL. Stosunki obu państw mają współcześnie złożony i niejednoznaczny charakter. Dynamicznie rozwijająca się wymiana handlowa prowadzi do rosnącej współzależności gospodarczej, czemu sprzyja komplementarny charakter obu gospodarek (dla Japonii atrakcyjny jest chiński rynek zbytu i potencjał wytwórczy, z kolei ChRL korzysta z japońskiego kapitału i technologii). Jednak relacje polityczne i w sferze bezpieczeństwa są wciąż nacechowane wysokim poziomem nieufności i pozostają wrażliwe na gwałtowne pogorszenie $\mathrm{w}$ wyniku różnorakich incydentów (jak np. ostatnie kontrowersje związane z zatrzymaniem przez japońską Straż Wybrzeża chińskich rybaków w pobliżu spornych wysp Senkaku/Diaoyutai). Duży potencjał konfliktogenny, który zawierają w sobie stosunki chińsko-japońskie ma kilka źródeł:

I. Rywalizacja o przywództwo w regionie - występowała ona już w czasach pax sini$c a$, chociaż prymat Chin nie został wówczas podważony. Od czasów rewolucji Meiji, dzięki radykalnemu i skutecznemu programowi modernizacji, Japonia uzyskała przewagę nad przeżywającymi kryzys Chinami cesarskimi. Mimo, iż mocarstwowa pozycja Japonii została złamana w wyniku klęski w II wojnie światowej, to powojenny „cud gospodarczy” pozwolił Japończykom na gospodarcze zdominowanie Azji. Obecnie pozycję tą przejmuje ChRL. Wystarczy przypomnieć, iż odebrała Japonii pozycję drugiej gospodarki świata (według kryterium nominalnego PKB).

II. Spory terytorialne - dotyczą one wysp Senakaku/Diaoyutai oraz rozgraniczenia stref wyłączności ekonomicznej na Morzu Wschodniochińskim. Chociaż terytoria 
będące przedmiotem sporu nie są pozbawione wartości strategicznej (głównie ze względu na znajdujące się tam złoża surowców naturalnych), to jednak trudno uznać kontrolę nad nimi za priorytetowy interes narodowy obu państw. W kalkulacjach przywódców chińskich kwestia wysp Senkaku/Diaoyutai nie ma znaczenia porównywalnego z innymi sporami terytorialnymi, jak Tajwan (który stanowi szczególny przypadek) czy Morze Południowochińskie. O tym, że kompromis w tych kwestiach jest możliwy świadczy porozumienie o wspólnej eksploatacji złóż gazu ziemnego w spornej części Morza Wschodniochińskiego (którego realizacja jest obecnie zawieszona). Wydaje się, iż spór w większym stopniu podtrzymują kwestie świadomości narodowej i uczuć nacjonalistycznych, które występują po obu stronach, jednak silniej objawiają się w ChRL. Dla wielu obywateli, zarówno ChRL, jak i Republiki Chińskiej na Tajwanie, „okupacja” wysp Diaoyutai przez Japończyków jest symboliczną pozostałością, ,wieku poniżenia”, gdy Chiny znajdowały się pod kontrolą mocarstw zewnętrznych. Warto zauważyć, iż incydenty związane ze statusem wysp są najczęściej prowokowane przez chińskie grupy pozarządowe, a władze czują się w obowiązku reagować, wobec spodziewanego nacisku nacjonalistycznie nastawionej opinii publicznej. Inaczej wygląda sytuacja na Morzu Wschodniochińskim, gdzie polityka rządu chińskiego jest znacznie bardziej aktywna. Jest to motywowane wyraźniej zarysowanymi interesami na tym obszarze, dotyczącymi złóż surowców energetycznych oraz dążeniem do uzyskania przez flotę wojenną swobody manewru na otwarte wody oceaniczne.

III. Rywalizacja o dostęp do surowców energetycznych i szlaków żeglugowych - zarówno ChRL, jak i Japonia są wielkimi importerami surowców energetycznych (przede wszystkim ropy naftowej), wobec czego niezakłócone funkcjonowanie ich gospodarek jest uzależnione od pewności dostaw z odległych regionów wydobywczych (w pierwszej kolejności Zatoki Perskiej). Wobec stale rosnącego popytu oraz ograniczonego wzrostu wydobycia pojawia się niebezpieczeństwo zaostrzonej rywalizacji o dostęp do źródeł dostaw. ChRL jest często oskarżana o rozumienie polityki bezpieczeństwa energetycznego jako „gry o sumie zerowej”. Wyraźnym przejawem chińsko-japońskiej rywalizacji o dostęp do surowców energetycznych jest historia projektu budowy rurociagu biegnącego z rosyjskich pól naftowych położonych w okolicach Angarska. Pierwotne plany zakładały poprowadzenie rurociagu do chińskiego miasta Daqing. W takim wypadku ChRL stałaby się faktycznie jedynym możliwym odbiorcą syberyjskiej ropy. Rząd japoński usilnie lobbował w Rosji na rzecz alternatywnego projektu, w myśl którego ropa miałaby płynąć do portu w Nachodce, nad Morzem Japońskim, skąd drogą morską można by ją eksportować do większej liczby odbiorców. Ostatecznie jednak, w efekcie mało przejrzystego (i pozornie chaotycznego) procesu decyzyjnego, przyjęto rozwiązanie kompromisowe. Zakłada ono, iż rurociąg będzie ostatecznie biegł do wybrzeża, jednak zostanie zbudowane odgałęzienie prowadzące do Chin ${ }^{29}$. Póki co, dzięki chińskim pożyczkom, najintensywniejsze prace są prowadzone właśnie na odcinku chińskim. Nie mniej istotna pozostaje w tym kontekście kwestia

29 L. Goldstein, V. Kozyrev, China, Japan and the Scramble for Siberia, „Survival” 2006, Vol. 48, No. 1. 
bezpieczeństwa szlaków żeglugowych, którymi surowce energetyczne są dostarczane do Azji Wschodniej. Biorąc pod uwagę rozbudowę i modernizację sił morskich, tak w Chinach, jak i w Japonii, w obu państwach rodzą się obawy, iż druga strona może w sytuacji kryzysowej użyć tego potencjału do odcięcia rywala od transportu morskiego. Jedną z przyczyn, dla których możliwość przyłączenia Tajwanu do ChRL budzi w Japonii duże obawy, jest strategiczne położenie wyspy względem szlaków żeglugowych prowadzących do Japonii.

IV. Spory o interpretację historii i głęboko zakorzeniona wrogość - w obu społeczeństwach występują głęboko zakorzenione uprzedzenia i postawy nieufności (lub wręcz otwartej wrogości) względem siebie nawzajem. Wynika to w dużej mierze z okoliczności w jakich formowała się nowoczesna świadomość narodowa Chińczyków i Japończyków. W przypadku Japonii była ona budowana na dumie z osiagnięć modernizacji Meiji i przynależności do świata rozwiniętego, czego przejawem było zanegowanie przynależności do Azji i poczucie wyższości względem innych zamieszkujących ją narodów. Natomiast tożsamość ChRL była budowana na fundamencie walki z dominacją obcych mocarstw nad Chinami. Pamięć o japońskiej agresji oraz oporze wobec niej stanowi nierozerwalny element tego dziedzictwa. Kampanie edukacji patriotycznej prowadzone przez władze chińskie utrwalały negatywny obraz Japonii w świadomości kolejnych pokoleń Chińczyków. Z drugiej strony, brak jednoznacznego rozliczenia się z wojenną przeszłością stanowi istotną przeszkodę dla rozwoju przyjaznych stosunków Japonii z resztą regionu. Symbolem trudności we wzajemnym zrozumieniu i pojednaniu między oboma narodami były kontrowersje i masowe protesty społeczne wywoływane przez wizyty japońskiego premiera w świątyni Yasukuni czy też dopuszczenie do użytku w niektórych japońskich szkołach podręczników historii uznawanych za „rewizjonistyczne” i fałszujące historię. Należy przy tym pamiętać, iż odmienne postrzeganie historii czy tradycyjna wrogość nie są same w sobie źródłami sporów i konfliktów w stosunkach chińsko-japońskich, ale w znacznym stopniu przyczyniają się one do eskalacji napięć wypływających z jak najbardziej współczesnych przesłanek i utrudniają ich kompromisowe rozwiązanie.

Warto pamiętać, iż od czasów Meiji Japonia miała do czynienia z Chinami jako partnerem znacznie słabszym, podczas gdy obecnie potęga ChRL dorównuje lub nawet przewyższa japońska. Gwałtowny wzrost znaczenia Chin na przestrzeni ostatnich dwóch dekad nie pozostał bez wpływu na pozycję Japonii w regionie. Pod względem gospodarczym, Chiny, między innymi dzięki znacznie większej otwartości swego rynku w porównaniu z Japonią, skutecznie przejmują pozycję lidera regionu. Szybka modernizacja chińskiego potencjału morskiego i powietrznego rodzi rosnące obawy w Japonii, zwłaszcza wobec coraz częstszych incydentów naruszania przestrzeni powietrznej i wód terytorialnych przez jednostki chińskie.

Także w okresie pozimnowojennym sojusz z USA pozostał jednym z najistotniejszych czynników określających kierunek japońskiej polityki zagranicznej i bezpieczeństwa. W nowych uwarunkowaniach międzynarodowych zmianie uległa ocena bilansu zysków i strat płynących z wzajemnej współpracy. Dla Japonii wzrosło poczucie zagrożenia zarówno opuszczeniem, jak i uwikłaniem. Amerykański sojusznik zaczął coraz bardziej zdecydowanie domagać się większego udziału Japonii w ochronie 
wspólnych interesów bezpieczeństwa, już nie tylko w regionie Azji i Pacyfiku, ale w skali globalnej. Trend ten był już widoczny w pierwszej połowie lat dziewięćdziesiątych (w związku z wojną w Zatoce Perskiej 1990-1991 oraz pierwszym koreańskim kryzysem nuklearnym 1993-1994). Uosobieniem nowych oczekiwań strony amerykańskiej były propozycje raportu komisji Nye-Armitaga przewidujące dla Japonii rolę

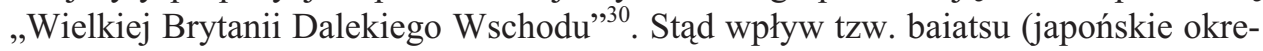
ślenie na naciski wywierane przez amerykańskiego sojusznika, traktowane jako czynnik kształtujący politykę) jako katalizatora reform w sferze polityki bezpieczeństwa stale rósł. Kulminacją tego trendu stał się udział Japonii w globalnej wojnie z terroryzmem i zaangażowanie Sił Samoobrony w działania w Afganistanie i Iraku. Nie da się jednak ukryć, iż „rewizjonistyczni” przywódcy (w tym zwłaszcza premier Koizumi) wykorzystywali baiatsu jako użyteczny argument na rzecz preferowanych przez nich rozwiązań. W sposób nieunikniony pojawiały się pytania o to, czy udział w amerykańskich operacjach militarnych rzeczywiście służy interesom narodowym Japonii. Bez wątpienia w okresie prezydentury G. Busha jr. obawy odnośnie możliwości uwikłania Japonii w amerykańskie wojny prewencyjne osiagnęły szczyt.

$\mathrm{Z}$ drugiej strony niemal bezwarunkowe poparcie polityki amerykańskiej w tamtym okresie stanowiło zabezpieczenie przed możliwością opuszczenia przez sojusznika w ważnych kwestiach regionalnych. Japonia jest obecnie bardzo wyczulona na zagrożenie ze strony Korei Północnej (przede wszystkim jej arsenału nuklearnego i rakietowego). W trakcie przedłużającego się (kolejnego już) kryzysu nuklearnego wśród japońskich decydentów pojawiła się opinia, iż Stany Zjednoczone w zasadzie pogodziły się już z faktem posiadania przez Koreę Północną broni nuklearnej, a ich główną troską jest zapobieżenie jej dalszej proliferacji. Tymczasem dla Cesarstwa najważniejszym celem jest denuklearyzacja półwyspu ${ }^{31}$. Japońskie elity z nieufnością patrzą również na wciąż zacieśnianą współpracę USA z ChRL. Coraz większa (i pozytywna) rola, jaką Chiny odgrywają w regionalnej (i globalnej) strategii USA prowadzi do obaw o możliwość „odwrócenia sojuszy”. Według tego scenariusza dynamicznie rozwijające się Chiny, o rosnących wpływach w regionie mogłyby być potencjalnie atrakcyjniejszym partnerem niż pogrążona w marazmie i izolacji Japonia.

Ryzyko i obawy po stronie amerykańskiej również wzrosły. Dotyczyły one zarówno możliwości niepożądanego uwikłania w japońskie konflikty z Koreą Północną, lub zwłaszcza z ChRL (w związku ze sporem terytorialnym o wyspy Senkaku/Diaoyou). Równocześnie nasiliła się krytyka niechęci sojusznika do rozwoju operacyjnego wymiaru sojuszu. Coraz wyraźniej zdawano sobie sprawę, iż w wypadku kryzysu nie będzie można liczyć na konkretne wsparcie zbrojne Japonii. Co więcej Cesarstwo udowodniło, iż w kwestiach żywotnych interesów narodowych jest gotowe prowadzić politykę niezależną, a nawet sprzeczną z amerykańską. Doskonałym przykładem jest

${ }^{30}$ Patrz np.: D. Asher, Could Japan become the „, Great Britain of the Far East?, „Asia-Pacific Review" 2001, Vol. 8, No. 2; J. J. Przystup, P. C. Saunders, Visions of Order: Japan and China in U.S. Strategy, „Strategic Forum” 2006, No. 220.

31 Patrz: C. H. Hughes, Not quite the 'Great Britain of the Far East': Japan's security, the US-Japan alliance and the 'war on terror' in East Asia, „Cambridge Review of International Affairs” 2007, Vol. 20, No. 2, oraz N. Bisley, op. cit., s. 89. 
historia kontraktu na eksploatację przez japońskie firmy pól naftowych w irańskim Azadeganie $^{32}$.

Okres pozimnowojenny charakteryzował się również istotnymi zmianami w polityce wewnętrznej Japonii, które stworzyły korzystne warunki dla reform w dziedzinie polityki bezpieczeństwa. „System 1955 roku” ulegał stopniowemu rozkładowi. Najistotniejszy z punktu widzenia omawianej tematyki był zmierzch Partii Socjalistycznej jako głównej siły opozycyjnej. Po tym jak lider socjalistów Tomichi Murayama stanął na czele koalicyjnego rządu z udziałem LDP jego formacja utraciła zaufanie większości tradycyjnych wyborców ${ }^{33}$. Wynikało to $\mathrm{z}$ faktu, iż ceną za udział w rządach było zanegowanie filarów całego powojennego programu politycznego lewicy w postaci uznania legalności Sił Samoobrony oraz zasadności sojuszu z USA. Marginalizacja sił politycznych reprezentujących postulaty pacyfizmu i antymilitaryzmu w znacznym stopniu ułatwiła przełamywanie ograniczeń nałożonych na politykę bezpieczeństwa w okresie powojennym.

Co więcej do zmiany układu sił doszło również wewnątrz LDP. Na początku XXI wieku władzę w partii przejęli „rewizjoniści”, którzy postulowali stopniowe odejście od doktryny Yoshidy. W minionej dekadzie trzech polityków kojarzonych z tą opcją pełniło funkcję premiera (Junichiro Koizumi, Shinzo Abe i Taro Aso). Wielkim ułatwieniem $\mathrm{w}$ realizacji ich programu było wzmocnienie pozycji premiera będące efektem reform administracyjnych przeprowadzonych za rządów premiera Ryutaro Hashimoto. Obejmowały one rozbudowę i wzmocnienie organów administracji bezpośrednio podległych szefowi rządu zwanych potocznie Kantei (od nazwy oficjalnej rezydencji premiera). Zaczęły one odgrywać znaczącą rolę w formułowaniu i egzekucji polityki zagranicznej. Mówi się nawet o tzw. „dyplomacji Kantei”, czyli sytuacji w której Sekretariat Gabinetu aktywnie wspiera premiera przy podejmowaniu decyzji politycznych i koordynuje ich wykonanie. Dzięki temu nastąpiła stopniowa ewolucja od tradycyjnego systemu „oddolnego" podejmowania decyzji (poprzez złożony proces partyjnych i biurokratycznych konsultacji) w stronę bardziej scentralizowanego modelu, w którym premier wspierany przez Kantei odgórnie narzuca decyzje polityczne ${ }^{34}$.

\section{Konsekwencje i prognozy}

Uwzględniając zarysowane powyżej trendy można przyjąć, iż ewolucja japońskiej polityki bezpieczeństwa w stronę tzw. „strategicznej normalności” będzie kontynuowana. Niepewne natomiast pozostaje tempo i ostateczny rezultat tego procesu. Międzynarodowe środowisko bezpieczeństwa Japonii raczej nie pozwoli na powrót do ograniczonej polityki w stylu Doktryny Yoshidy. Chociaż sytuacja w Azji pozostaje dynamiczna, to jednak rozwój sytuacji na Półwyspie Koreańskim oraz postępująca asertywność władz ChRL na arenie międzynarodowej sugerują raczej pogłębienie

32 Patrz: M. H. Armacost, Japan Tilting Closer to Washington, w: Strategic Asia 2003-04: Fragility and Crisis, eds. R. J. Ellings, A. L. Friedberg, M. Wills, Seattle 2003, s. 94.

33 K. B. Pyle, op. cit., s. 298-299.

34 T. Shinoda, op. cit., s. 63-85. 
niepewności w regionie, co z kolei będzie silnym bodźcem na rzecz prowadzenia aktywnej polityki bezpieczeństwa. Co więcej, w ciągu ostatnich dwóch dekad osłabieniu uległy dwa filary zimnowojennej polityki bezpieczeństwa Japonii, tj. pozycja USA w regionie oraz siła instrumentów ekonomicznych pozostających w dyspozycji rządu japońskiego.

Stany Zjednoczone wciąż pozostają największą potęgą militarną w skali globalnej i regionalnej, jednak ich pozycja (szczególnie w sferze gospodarczej i dyplomatycznej) jest zagrożona przez wzrost tzw. „potęg wschodzących” (w szczególności ChRL). Wraz ze zmieniającym się stosunkiem sił zdolność i chęć USA (zwłaszcza wobec kosztownego zaangażowania na Bliskim Wschodzie) do zapewnienia Japonii bezpieczeństwa może być poddawana w wątpliwość. Jednocześnie marazm, w jakim od dwóch dekad pogrążona jest japońska gospodarka, oraz wzrost potęgi gospodarczej innych państw regionu (zwłaszcza ChRL) sprawiaja, iż ekonomiczne środki oddziaływania wspierające politykę zagraniczną są znacznie słabsze i przez to mniej skuteczne niż jeszcze np. pod koniec lat osiemdziesiątych. Trzeba również pamiętać o tym, iż na japońskiej scenie politycznej pojawiły się zarysy konsensusu co do utrzymania obecnego kierunku polityki bezpieczeństwa. Demokratyczna Partia Japonii po przejęciu władzy w wyniku wyborów do Izby Reprezentantów z sierpnia 2009 r. nie dokonała żadnych radykalnych zmian w tej dziedzinie (za wyjątkiem zakończenia misji Morskich Sił Samoobrony na Oceanie Indyjskim).

Nie można jednak zapominać o istotnych czynnikach ograniczających dalszą ,,normalizację" japońskiej polityki bezpieczeństwa. Jednym z najpoważniejszych jest (dotykający zresztą całokształtu polityki państwowej) kryzys przywództwa politycznego oraz brak spójnej wizji politycznej i gospodarczej przyszłości państwa. Od czasu ustapienia Junichiro Koizumiego ze stanowiska szefa rządu w 2006 roku, Japonia miała 5 premierów. Mimo zdecydowanego zwycięstwa w ostatnich wyborach DPJ pozostaje wewnętrznie podzielona i ma trudności ze sformułowaniem całościowej wizji reform, które chciałaby podjąć. W dziedzinie polityki bezpieczeństwa symbolem tego niezdecydowania było postępowanie rządu premiera Yukio Hatoyamy względem kwestii przeniesienia bazy lotniczej amerykańskiej piechoty morskiej Futenma na Okinawie. Najpierw w kampanii wyborczej przyszły premier osobiście obiecał mieszkańcom wyspy, iż baza zostanie z niej trwale usunięta. Później jednak wobec kryzysu, jaki kwestia ta wywołała w stosunkach z sojusznikiem szukał rozwiązania kompromisowego, aż ostatecznie pozostano przy dotychczasowych planach relokacji bazy w ramach Okinawy, co doprowadziło do rezygnacji premiera.

Nie mniej istotną kwestią (jak trafnie zauważyli T. Yoshihara oraz J. R. Holmes ${ }^{35}$ ) jest zapewnienie finansowych podstaw dla dalszego poszerzania spektrum misji i rozbudowy potencjału Sił Samoobrony. Obecnie japońscy przywódcy wymagaja, aby Siły Samoobrony realizowały coraz więcej misji przy niezmienionym budżecie. Pełna „normalizacja” polityki obronnej wymagałaby o wiele wyższych nakładów finansowych. Trudna sytuacja finansów publicznych (Japonia ma obecnie najwyższy poziom długu publicznego w relacji do PKB spośród państw wysokorozwiniętych) czyni taki

35 T. Yoshihara, J. R. Holmes, Japan's Emerging Maritime Strategy: Out of Sync or Out of Reach?, „Comparative Strategy” 2008, No. 27. 
scenariusz mało realnym. Problemem może być również niedostatek zasobów ludzkich. Według prognozy Narodowego Instytutu Badań nad Populacją i Bezpieczeństwem Socjalnym w 2050 roku Cesarstwo będzie miało jedynie 95 mln mieszkańców (obecnie 127 milionów), w tym $2 / 5$ ludzi starszych (w wieku poprodukcyjnym) ${ }^{36}$. Siły Samoobrony od początku swego istnienia napotykały na spore trudności w osiaganiu zakładanych stanów osobowych. Wraz z postępem niekorzystnych trendów demograficznych będą one z pewnością narastać. Co prawda Biała Księga Obronności wydana przez Ministerstwo Obrony w 2010 roku podkreśla, iż rozwiązaniem tego problemu może być substytucja siły żywej nowoczesnymi technologiami ${ }^{37}$. Należy jednak pamiętać, iż technika nie jest w stanie w pełni zastapić ludzi i oczywiście sama jest bardzo kosztowna.

Wciąż aktualna pozostaje analiza K. B. Pylea i E. Heginbothama z początku wieku kreśląca pięć możliwych scenariuszy strategii Japonii w XXI wieku ${ }^{38}$. Scenariusz pierwszy przewiduje bilateralną strategię proamerykańską, oznaczającą dalsze zacieśnianie sojuszu oraz traktowanie go jako instrumentu wzmacniania bezpieczeństwa regionalnego, a nawet globalnego. Scenariusz drugi - regionalna strategia azjatycka - prowadzić ma do rozluźnienia związków z USA (ale bez zrywania sojuszu) oraz pogłębionej integracji (w pierwszej kolejności gospodarczej) z pozostałymi państwami Azji Wschodniej i Południowo-Wschodniej. Globalna strategia instytucjonalna jako trzeci możliwy scenariusz, upatruje w silnym zaangażowaniu na rzecz globalnych instytucji wielostronnych (np. ONZ) drogę do statusu mocarstwowego oraz zapewnienia bezpieczeństwa własnego państwa. Scenariusz czwarty to kontynuacja dotychczasowej strategii wszechstronnego bezpieczeństwa, zaś piąty - strategia unilateralna (Gaullistowska) - oznacza remilitaryzację, anulowanie sojuszu z USA i próby zapewnienia sobie bezpieczeństwa własnymi środkami.

$Z$ dużą dozą prawdopodobieństwa można założyć, iż realny kształt polityki Cesarstwa nie będzie wprost odpowiadał żadnemu $\mathrm{z}$ tych teoretycznych modeli. Można raczej oczekiwać wzajemnego przenikania się i uzupełniania poszczególnych orientacji. Model wszechstronnego bezpieczeństwa nadal silnie oddziałuje na poglądy elit strategicznych Japonii. Ostatnie gabinety LDP (przede wszystkim J. Koizumiego, S. Abe oraz T. Aso) próbowały realizować strategię bilateralną przy wsparciu administracji G. Busha jr. Obecny rząd DPJ, przynajmniej w sferze deklaracji przewiduje politykę zorientowaną bardziej regionalnie. Strategia unilateralna nigdy nie miała zbyt wielu znaczących politycznych zwolenników. Nie tylko byłaby ona niezwykle kosztowna (ze względu na przejecie pełnej odpowiedzialności za bezpieczeństwo i obronność), ale także wywołałaby falę silnych obaw, a nawet wrogości w regionie.

Warto jeszcze raz podkreślić, iż koncepcja wszechstronnego bezpieczeństwa przykłada równą wagę do bezpieczeństwa militarnego i ekonomicznego. W tym kontekście można rozpatrywać obecną japońską politykę jako strategię ,rozdwojoną” opartą na

36 Japanese immigration. Don't bring me your huddled masses, „The Economist”, 3.01.2009, http://www.economist.com/world/asia/displaystory.cfm?story_id=E1_TNRGSPNR (22.11.2009).

37 Defence of Japan 2010, http://www.mod.go.jp/e/publ/w_paper/2010.html (25.10.2010).

38 K. B. Pyle, E. Heginbotham, Japan, w: Strategic Asia 2001-02 Power and Purpose, eds. R. J. Ellings A. L. Friedberg, op. cit., s. 82-92. 
dwóch filarach. W sferze gospodarczej Japonia jest coraz bardziej powiązana z regionem, jednak w sferze strategiczno-militarnej nadal polega na sojuszu z USA. W ramach tego podejścia można założyć, iż Japonia będzie dążyć do pogłębienia integracji gospodarczej z Azją (np. poprzez takie instytucje jak ASEAN+3 czy EAS). Jednak między Japonią a innymi państwami regionu (dotyczy to zwłaszcza Chin) istnieją zbyt duże różnice interesów, pokłady nieufności oraz potencjał rywalizacji, aby integrację tą można było w przewidywalnej przyszłości przenieść na płaszczyznę polityczną. Stąd drugim filarem japońskiej strategii będzie zapewne utrzymanie bliskiego sojuszu polityczno-wojskowego ze Stanami Zjednoczonymi, jako filaru militarnego bezpieczeństwa i zabezpieczenie przed potencjalnymi zagrożeniami płynącymi z kontynentu.

Japońska polityka ostatniej dekady zmierza w tym kierunku. Rządy konserwatywne skłaniały się ku bliższej współpracy z USA, ale równocześnie starały się o rozwój regionalnej współpracy gospodarczej. Z kolei nowy rząd demokratów kładzie większy nacisk na azjatycki wymiar polityki zagranicznej, jednak zależy mu także na podtrzymaniu sojuszu. Żaden z wariantów nie wyklucza zwiększenia zaangażowania w wielostronne fora międzynarodowe. Zwolenników elementów strategii globalnej można znaleźć po obu stronach japońskiej sceny politycznej (tzn. zarówno w LDP, jak i DPJ). Jednak można wątpić, aby miała się ona stać podstawowym wyznacznikiem strategii narodowej. Przemawia za tym obserwowalna zwłaszcza w ostatnich latach niezdolność organizacji międzynarodowych do rozwiązywania istotnych problemów międzynarodowych (zwłaszcza z zakresu bezpieczeństwa). Trzeba również pamiętać, iż szerokie zaangażowanie na skalę globalnąjest kosztowne, być może zbyt kosztowne dla przeżywającej długotrwałe trudności japońskiej gospodarki.

O ile strategia rozdwojenia (oparcia bezpieczeństwa militarnego na sojuszu, a pomyślności gospodarczej na regionalnej integracji) mogłaby okazać się wysoce korzystna dla Japonii, to nie jest pewne czy udałoby się ją utrzymać w dłuższej perspektywie. Jeżeli ogólny stan stosunków w regionie będzie przyjazny, tzn. przede wszystkim jeśli USA i ChRL będą nastawione w większym stopniu na współpracę niż rywalizację, to strategia „rozdwojenia” może okazać się skuteczna. Jeżeli natomiast doszłoby do znaczącego konfliktu interesów Japonia musiałaby wybrać między swoim głównym partnerem gospodarczym (Chinami) a partnerem strategicznym (USA).

Japończyków można uznać za pionierów współczesnego tzw. „,szerokiego” rozumienia bezpieczeństwa narodowego. Wyrazem tego była koncepcja „wszechstronnego bezpieczeństwa" sformułowana na początku lat osiemdziesiątych, chociaż obecna w praktyce japońskiej polityki bezpieczeństwa już znacznie wcześniej. Należy jednak pamiętać, iż prowadzenie „zdemilitaryzowanej” polityki bezpieczeństwa było możliwe w dużej mierze dzięki temu, iż tradycyjne bezpieczeństwo militarne było zapewniane przez amerykańskiego sojusznika. W okresie pozimnowojennym, kiedy to wydawało się, iż „nowe” podejście stanie się powszechnie obowiązującym, zmiany w środowisku bezpieczeństwa wymusiły na Japonii zwrot w stronę bardziej tradycyjnej polityki. Prowadzi to do wniosku, iż założenia „wszechstronnego bezpieczeństwa" nie zdezaktualizowały się kompletnie, jednak tradycyjny komponent militarny pozostaje niezbędnym i podstawowym elementem każdej polityki bezpieczeństwa narodowego. 


\title{
STRESZCZENIE
}

Polityka bezpieczeństwa Cesarstwa Japonii w okresie po II wojnie światowej jest nieprzerwanie obiektem żywego zainteresowania, zarówno praktyków, jak i badaczy stosunków międzynarodowych. Wynika to $\mathrm{z}$ dwóch zasadniczych przesłanek. Pierwszą stanowi tradycyjnie istotna pozycja tego państwa w międzynarodowym układzie sił regionu Azji (którego znaczenie dla ładu globalnego stale rośnie). Druga wynika z faktu, iż u zarania zimnej wojny japońscy przywódcy przyjęli oryginalną strategię polityki zagranicznej i bezpieczeństwa, opartą na wyrzeczeniu się instrumentów siłowych i ograniczeniu potencjału obronnego do niezbędnego minimum. Taka polityka mocno kontrastowała z poczynaniami innych znaczących aktorów ówczesnego ładu międzynarodowego. Była również trudna do wytłumaczenia z punktu widzenia tradycyjnej perspektywy wyjaśniania stosunków międzynarodowych (opartej na realizmie politycznym), w myśl której wzrost potencjału gospodarczego państwa powinien prowadzić do mocarstwowych aspiracji i wzmożonych zbrojeń. Niezwykle intrygującym pozostaje fakt, iż zasadnicza transformacja ładu międzynarodowego (tak w wymiarze globalnym, jak i regionalnym), którą przyniósł koniec zimnej wojny, zapoczątkowała proces ewolucji japońskiej polityki bezpieczeństwa w przeciwnym od dotychczasowego kierunku. Bardziej niepewne środowisko bezpieczeństwa, uwarunkowania sojuszu z USA, oraz istotne zmiany w systemie politycznym państwa doprowadziły do stopniowego odejścia od formuły drastycznie ograniczonego potencjału obronnego na rzecz rozbudowy sił zbrojnych i wypełniania przez nie coraz szerszego wachlarza misji. Odpowiedź na pytanie o treść i zakres tych zmian, ich przyczyny oraz konsekwencje ma istotne znaczenie dla analizy obecnego i przyszłego kształtu środowiska bezpieczeństwa międzynarodowego w Azji.

\section{THE EVOLUTION OF JAPANESE SECURITY POLICY AFTER THE COLD WAR. FROM THE „MORATORIUM STATE” TO STRATEGIC „NORMALITY”}

\begin{abstract}
The security policy of the Empire of Japan in the post-World War II period is a subject of lively interest among both policymakers and scholars in the field of international relations. There are two basic reasons for that. The first one comes from the traditionally important position occupied by this state in regional balance of power in Asia (which significance for the global order constantly rises). The second reason comes from a fact, that at the beginning of the cold war, Japanese leaders adapted a peculiar foreign policy and security strategy, based on disavowal of the instrument of force and limitation of the defense potential to the indispensable minimum. This policy stood in stark contrast with the common practices of the cold war international order. It was also difficult to explain from the perspective of traditional IR theory (based on political realism), which stats that the rise of state's economic power should lead to great power aspirations and intensive arms build-up. It is intriguing, that the fundamental transformation of the international order, brought by the end of the cold war, initiated a process of change in Japanese security policy, which lead in exactly opposite direction. More unstable regional environment, changes in alliance policy and important changes in domestic political system, all determine an expansion of armed forces and widening of its mission spectrum. The nature and scope of these changes, as well as their causes and effects are extremely important for the analysis of the current and future security environment of Asia.
\end{abstract}


